\title{
MicroRNA-410-3p attenuates gemcitabine resistance in pancreatic ductal adenocarcinoma by inhibiting HMGB1-mediated autophagy
}

\author{
Junjie Xiong ${ }^{1, *}$, Dan Wang ${ }^{2, *}$, Ailin Wei ${ }^{1,3}$, Nengwen $\mathrm{Ke}^{1}$, Yichao Wang ${ }^{4}$, Jie Tang ${ }^{5}$, \\ Sirong $\mathrm{He}^{6}$, Weiming $\mathrm{Hu}^{1}$ and Xubao Liu ${ }^{1}$ \\ ${ }^{1}$ Department of Pancreatic Surgery, West China Hospital of Sichuan University, Chengdu 610041, China \\ ${ }^{2}$ Department of Respiratory and Critical Care Medicine, West China Hospital of Sichuan University, Chengdu 610041, China \\ ${ }^{3}$ Key Laboratory of Transplant Engineering and Immunology, Ministry of Health, Regenerative Medicine Research Center, \\ West China Hospital, Sichuan University, Chengdu 610041, China \\ ${ }^{4}$ Department of Thyroid Surgery, West China Hospital of Sichuan University, Chengdu 610041, China \\ ${ }^{5}$ State Key Laboratory of Biotherapy, Sichuan University, Chengdu 610041, China \\ ${ }^{6}$ Department of Immunology, College of Basic Medicine, Chongqing Medical University, Chongqing 400016, China \\ *These authors contributed equally to this work
}

Correspondence to: Xubao Liu, email: liuxb2011@126.com

Keywords: PDAC; miR-4 10-3p; chemoresistance; HMGB1; autophagy

Received: June 19, $2017 \quad$ Accepted: October 30, $2017 \quad$ Published: November 18, 2017

Copyright: Xiong et al. This is an open-access article distributed under the terms of the Creative Commons Attribution License 3.0 (CC BY 3.0), which permits unrestricted use, distribution, and reproduction in any medium, provided the original author and source are credited.

\section{ABSTRACT}

Gemcitabine-based chemotherapy is the most common treatment option for pancreatic ductal adenocarcinoma (PDAC). However, it offers little therapeutic value in many cases due to the rapid development of chemoresistance. MicroRNAs (miRNAs) have been found to play pivotal roles in the chemotherapeutic resistance of PDAC. We found that miR-410-3p was significantly down-regulated in human pancreatic cancer xenograft (HPCx) tumor tissues from gemcitabine-treated mice. Low miR410-3p expression correlated with gemcitabine resistance in HPCX tumors and PDAC cells as well as poor prognosis in PDAC patients. We also found that miR-410-3p attenuated the gemcitabine resistance of PDAC by targeting the $3^{\prime}$-UTR of HMGB1. Moreover, our study clearly demonstrated that miR-410-3p enhanced chemosensitivity to gemcitabine via inhibiting HMGB1-induced autophagy during chemotherapy in PDAC cells. Our study suggests that miR-410-3p expression may be a useful indicator of the potential for chemoresistance to gemcitabine and provide a potential new therapeutic target for chemoresistance in PDAC.

\section{INTRODUCTION}

Pancreatic ductal adenocarcinoma (PDAC) is one of the main causes of cancer-related death in developed countries and is considered to be an incurable and rapidly lethal disease [1]. The prognosis of patients after complete resection is poor, and $>50 \%$ of patients develop tumor recurrence, with an estimated 5 year survival of only $20 \%$ [2]. Recent reports have suggested that adjuvant chemotherapy following curative surgery significantly prolonged the overall survival time after surgery, and this approach is being adopted as a standard strategy $[3,4]$. The majority of PDACs are sensitive to gemcitabine at first [5], and gemcitabine-based chemotherapy has formed the core of adjuvant therapy for PDAC [3]. Unfortunately, gemcitabine is only modestly effective against tumor recurrence and extends overall survival (OS) by approximately 6 months. PDAC will eventually develop resistance to gemcitabine after prolonged exposure [6]. One of the most important factors affecting the poor prognosis of PDAC is considered to be its high resistance to most of the existing chemotherapeutic regimens.

MicroRNAs (miRNAs) are small non-coding RNAs that interact with mRNA and serve as negative regulators of gene expression by targeting the 3 '-UTR mRNA region of the target mRNAs, inhibiting their translation or leading to 
their degradation $[7,8]$. miRNAs have been found to play pivotal roles in PDAC development and progression by affecting multiple cellular processes, such as cell apoptosis, survival and chemotherapeutic resistance of PDAC $[9,10]$. MiR-15a [11], miR-21 [12, 13], miR-34 [14], members of the miR-200 family $[12,15]$, miR-214 [11], miR-221 [16], members of the let7 family [15], and miR-320c [17] have been reported to play roles in gemcitabine chemoresistance in pancreatic cancer. Clinical studies have demonstrated the efficacy of miRNA as a therapeutic tool in the management of PDAC [18, 19]. Studies in vitro and in vivo have demonstrated the tremendous efficacy of miRNA as a therapeutic tool in the chemoresistance of PDAC to gemcitabine by regulating chemoresistance-related miRNAs. Down-regulation of miR-21 [20] and miR-125a [21] enhanced gemcitabine sensitivity in human pancreatic cancer cells. Up-regulation of miR-33a [22, 23], miRNA181b [24] and miR-211 [25] increased the sensitivity of PDAC cells to gemcitabine in vitro and in nude mice.

In this study, we demonstrated that low miR-410-3p expression was associated with gemcitabine resistance in HPCx tumors and PDAC cells as well as poor prognosis in PDAC patients. Moreover, we found that up-regulated expression of miR-410-3p improved the chemoresistance of PDAC by targeting the 3'-UTR sequences of HMGB1 and inhibiting HMGB1-mediated autophagy signaling. As a result, this study provides a potential new strategy to enhance chemosensitivity of PDAC to gemcitabine.

\section{RESULTS}

\section{Identification of chemoresistance-related miRNAs by miRNA microarray analysis}

To identify potential miRNAs related to gemcitabine resistance in pancreatic cancer, we performed a miRNA microarray analysis in human pancreatic cancer xenograft (HPCx) subpopulations resistant to gemcitabine treatment. When the HPCx tumor volumes reached $>80 \mathrm{~mm}^{3}$, mice were treated with gemcitabine, and the nodules were removed after 3 weeks. HPCx tumors from untreated mice were removed to serve as controls. Figure 1A shows that, among the 43 miRNAs whose expression levels were altered more than 1.5-fold, 13 candidate miRNAs were down-regulated in HPCx tumor tissues from gemcitabinetreated mice compared to their expression in controls tissues. Real-time PCR confirmed that miR-34-5p (Figure 1B), miR-410-3p (Figure 1C), miR-449-5p (Figure 1D) and miR-203 (Figure 1E) were down-regulated in HPCX tumor tissues from gemcitabine-treated mice $(P<0.05)$.

\section{miR-410-3p promotes the sensitivity of human PDAC to gemcitabine}

Gemcitabine-resistant clones of human PDAC cells were shown to be significantly more drug resistant to gemcitabine (Figure 2A, 2B). To evaluate the effect of miR-34-5p, miR-410-3p, miR-449-5p and miR-203 on the response to gemcitabine in human PDAC cells, mimics of these miRNAs were introduced into gemcitabine-resistant clones of human PDAC cells (Supplementary Figure 1). We found that up-regulation of miR-410-3p expression significantly inhibited chemoresistance to gemcitabine in human PDAC cells (Figure 2B, 2C). In contrast, the chemoresistance to gemcitabine was merely slightly repressed in human PDAC cells treated with miR-34-5p or miR-203 mimics (Supplementary Figure 2). Otherwise, anti-miR-410-3p transfection into human PDAC cells, whose endogenous levels of miR-410-3p were sufficiently inhibited (Supplementary Figure 1), resulted in significant augmentation of chemoresistance to gemcitabine in human PDAC cells (Figure 2B, 2D). We also examined the association between miR-410-3p expression and the clinicopathological features of 86 PDAC patients who received gemcitabine chemotherapy after radical surgical resection. There was no statistically significant association between miR-410-3p expression and the clinicopathological parameters (Supplementary Table 1). Kaplan-Meier survival analysis showed that PDAC patients with low miR-410$3 p$ expression had a shorter overall survival (OS) time (Figure 2E, $P=0.018$ ) and disease-free survival (DFS) time (Figure 2F, $P=0.037$ ) than those with high miR-410$3 p$ expression. These results demonstrated that low miR410-3p expression correlated with gemcitabine resistance and poorer prognosis in human PDAC. To further confirm the function of miR-410-3p in gemcitabine sensitivity, we transplanted gemcitabine-resistant clones of human PDAC cells into mice that were then treated with gemcitabine or saline control. Overexpression of miR-410-3p significantly promoted the reduction in tumor volume (Figure $2 \mathrm{G}$ ), tumor weight (Figure 2H), and apoptosis (Figure 2I, 2J) in tumors tissues caused by gemcitabine treatment. Taken together, these results confirmed that miR-410-3p attenuated the gemcitabine resistance of PDAC in vivo and vitro.

\section{Predicting and validating the gene targets of miR-410-3p that affected gemcitabine resistance}

To examine in more detail the function of miR-410-3p in the sensitivity of pancreatic cancer to gemcitabine treatment, we used online programs (TargetScanHuman 7.1 and MicroRNA.org) to search for potential targets of miR-410-3p and to identify those putative targets that might be related to chemosensitivity. Thirty gene candidates were found to be potential targets of miR410-3p by both programs (Figure 3A, Table 1). We analyzed the expression of the 30 putative target genes after modification of the expression of miR-410-3p in human PDAC cells via up/down-regulation of miR-410-3p expression by transfection with miR-410-3p mimics or anti-miR-410-3p oligonucleotide, respectively. Eleven potential targets (ARFIP1, HMGB1, GRIA2, CPEB4, 
NDFIP2, KLF6, PARG, OTX2, TMEFF2, TRPC1 and KLHL5) were significantly affected by the miR-410-3p expression modifications (Figure 3B). By examining these 11 potential targets, we further found that only HMGB1 was significantly expressed in gemcitabine-resistant PDAC cells (Figure 3C), indicating that HMGB1 might be related to chemosensitivity. A luciferase assay was performed to further confirm that miR-410-3p can directly target the 3'-UTR of HMGB1 (Figure 3D, 3E). Figure 3F illustrates that HMGB1 was shown to be down-regulated by $\mathrm{miR}-410-3 \mathrm{p}$ overexpression and up-regulated by miR$410-3 p$ silencing at the protein level in human PDAC cells (Figure 3G). These results showed that HMGB1 was a direct target of miR-410-3p and might be related to gemcitabine resistance in human PDAC cells.

\section{Down-regulation of HMGB1 is essential for the miR-410-3p-attenuated gemcitabine resistance in human PDAC cells}

As a nuclear protein, the expression and translocation of HMGB1 plays a critical role in the response to chemotherapy in cancer [26]. Therefore, we examined whether the expression and translocation of HMGB1 correlated with gemcitabine resistance in human PDAC cells. The level of HMGB1 mRNA was significantly increased in gemcitabine-resistant clones of human PDAC cells (Figure 4A). Western blot (Figure 4B, 4C) and immunofluorescence (Figure 4D) analysis indicated a prominent cytoplasmic expression of HMGB1 in gemcitabine-resistant PDAC cells. Moreover, we transfected gemcitabine-resistant PDAC cells with HMGB1 siRNA (Figure 4A) and found that HMGB1 silencing significantly inhibited gemcitabine resistance (Figure 4E, 4F) to a level similar to that of cells treated with miR-410-3p mimics. To further investigate whether HMGB1 was responsible for the miR-410-3p-attenuated gemcitabine resistance in human PDAC cells, gemcitabine-resistant PDAC cells were treated with miR-410-3p mimics and/or HMGB1 gene transfection. Exogenous miR-410-3p significantly reduced the expression and translocation (Figure $4 \mathrm{G}-4 \mathrm{~J}$ ) of HMGB1 and increased the gemcitabine chemosensitivity (Figure 4K, 4L) of human PDAC cells. More important, when the expression of HMGB1 was increased by HMGB1 gene transfection (Figure 4J), miR-410-3p treatment did not repress the gemcitabine resistance in human PDAC cells (Figure 4K, 4L). Thus, HMGB1 mediates the effects of miR-410-3p on the chemosensitivity of human PDAC cells to gemcitabine.

\section{MiR-410-3p inhibits HMGB1-mediated autophagy in human PDAC cells during chemotherapy}

Tumor cells use cytoprotective autophagy as a defense from apoptotic cell death, which in turn contributes to the
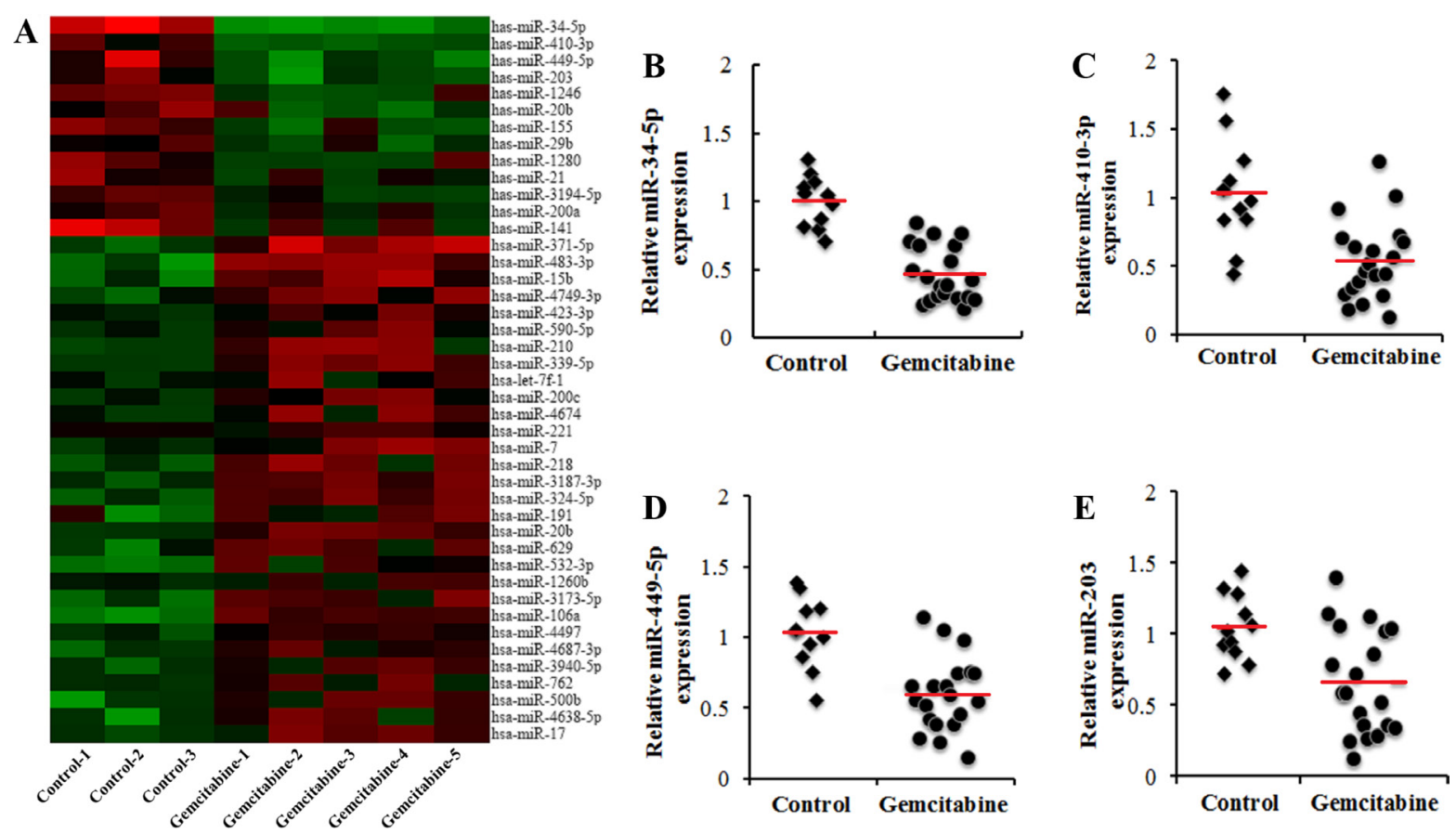

Figure 1: Identification of chemoresistance-related miRNAs in human pancreatic cancer xenografts (HPCx) tissues. (A) miRNA microarray analysis of candidate miRNAs. The heat map revealed the miRNAs whose expression levels were altered $>2$ or $<-2$-fold in HPCx tumor tissues from gemcitabine-treated mice relative to expression in tissues from control mice $(n=11 \sim 20)$. miR-34-5p (B), miR-410-3p (C), miR-449-5p (D) and miR-203 (E) expression, determined by Real-time PCR, was down-regulated in HPCx tumor tissues from gemcitabine-treated mice $(p<0.05)$. 
development of chemoresistance [27, 28]. To investigate whether gemcitabine treatment induced autophagy in human PDAC cells, cells were treated with $50 \mathrm{ng} / \mathrm{ml}$ of gemcitabine for $48 \mathrm{~h}$ as in previous studies [29, 30]. In our study, chemotherapy-stimulated autophagy in human PDAC cells was also confirmed by assays examining the expression of autophagy-related biomarkers. The number of GFP-LC3 fluorescent dots and the accumulation of LC3 puncta in PDAC cells that stably expressed GFP-LC3 was significantly higher in the gemcitabine treatment groups (Figure 5A), and significantly high levels of LC3-I/-II conversion and Beclin1 expression were also observed in PDAC cells treated with gemcitabine (Figure 5B, 5D, 5E). The interaction of HMGB1 with Beclin1 and LC3 plays a role in the facilitation of autophagy following cytotoxic insults [31-33]. Thus, we further determined the correlation of the high autophagy level following chemotherapy with the up-regulation of HMGB1 in human PDAC cells. We knocked
A

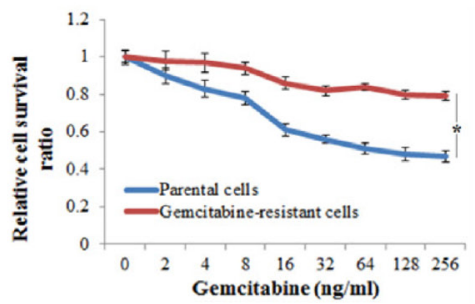

B
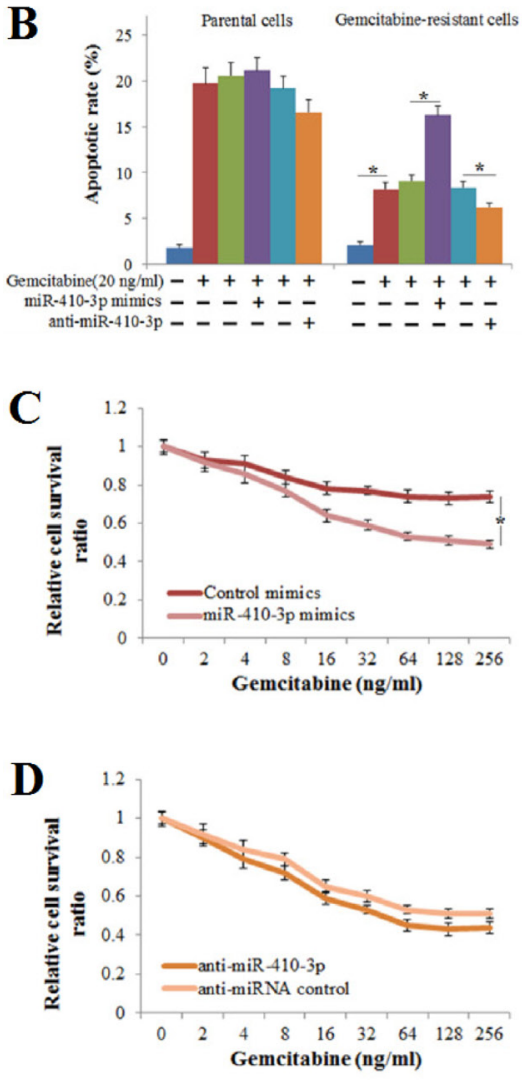
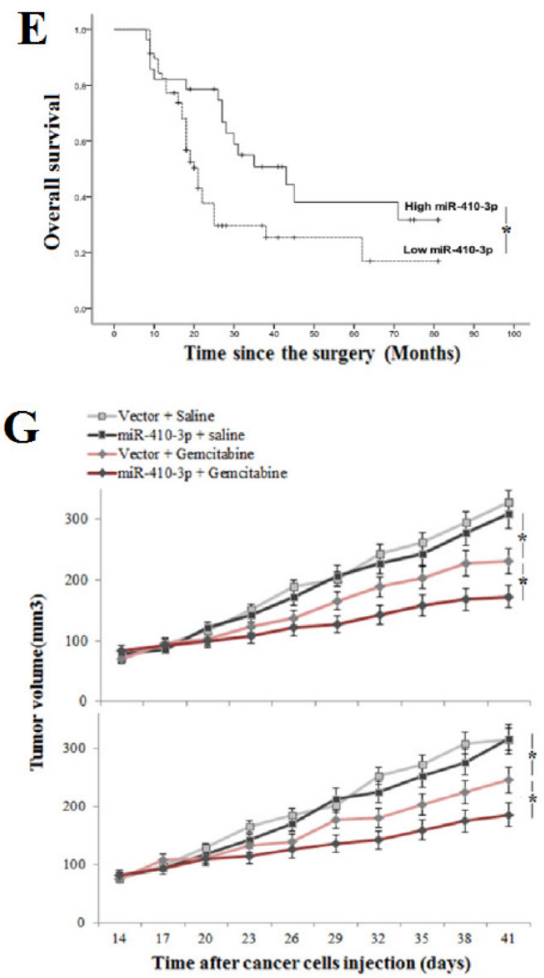

Time after cancer cells injection (days)

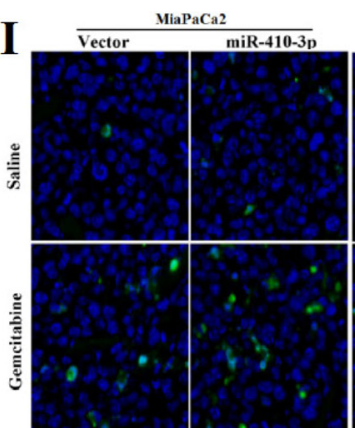

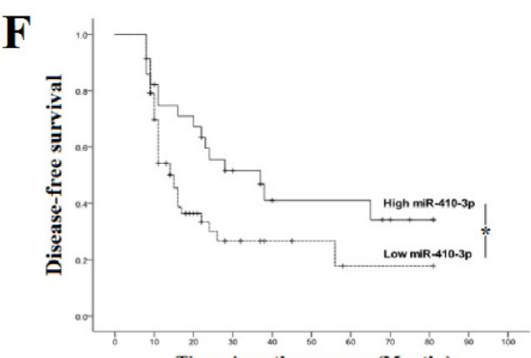

Time since the surgery (Months)

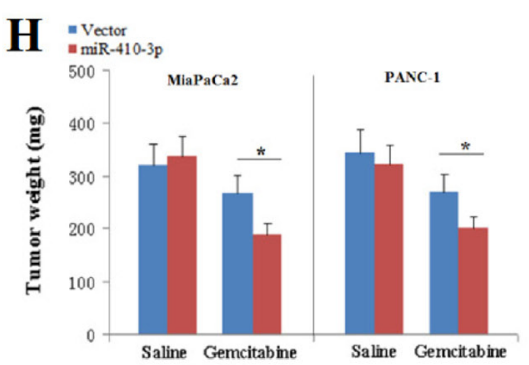

Figure 2: Association of miR-410-3p expression with the sensitivity to gemcitabine and the prognosis. Growth-inhibitory effects (A) of gemcitabine on gemcitabine-resistant and parental clones of human PDAC cells were assessed by MTT assay. The apoptotic rate (B) of human PDAC cells (annexin V/PI double-positive cells) treated with $50 \mathrm{ng} / \mathrm{ml}$ gemcitabine were analyzed by FCM assay, and the growth-inhibitory effects of gemcitabine on gemcitabine-resistant clones of human PDAC cells treated with miR-410-3p mimics (C) and anti-miR-410-3p (D) were assessed by MTT assay. PDAC patients were divided into a low miR-410-3p expression group and high miR-410-3p expression group, according to the real-time PCR results. OS (E) and DFS (F) curves of PDAC patients with low or high miR-410-3p expression were drawn with the log-rank test. Human PDAC cells (MiaPaCa2 cell and PANC-1 cell) expressing miR-410-3p or a control vector were subcutaneously transplanted in mice. Mice were treated with gemcitabine or saline $(n=11 \sim 20)$. Tumor volume (G) and tumor weight $(\mathbf{H})$ were measured. The number of apoptotic cells in the tumor specimens was determined using TUNEL staining (I). The TUNEL kit stained apoptotic cells green, while the nuclei were stained blue using DAPI. The rate of apoptosis (J) was determined by counting the TUNEL-stained cells in the specimen. All of the treatments in this figure were carried out in triplicate, and the results are displayed as the means \pm SD. ${ }^{*} P<0.05$. 
out HMGB1 in human PDAC cells (Figure 5B, 5C) and then treated them with gemcitabine. As expected, HMGB1 knockdown in gemcitabine-treated cells decreased the levels of autophagy as shown by the decrease in LC3 punctae, LC3-I/II conversion and Beclin1 expression (Figure 5A, 5B, 5D, 5E). These results confirmed that HMGB1 mediated autophagy during chemotherapy in PDAC cells. Our studies had previously shown that HMGB1 was a direct target of miR-410-3p in PDAC cells; therefore, we investigated this effect further to determine whether miR-410-3p could suppress HMGB1-mediated autophagy in human PDAC cells during chemotherapy. MiR-410-3p overexpression significantly decreased LC3 punctae, LC3-I/II conversion and Beclin1 expression, while miR-410-3p silencing increased LC3 punctae, LC3-I/II conversion and Beclin1 expression (Figure 5F-5I). These results revealed that overexpression of miR-410-3p can inhibit HMGB1-mediated autophagy in human PDAC cells.

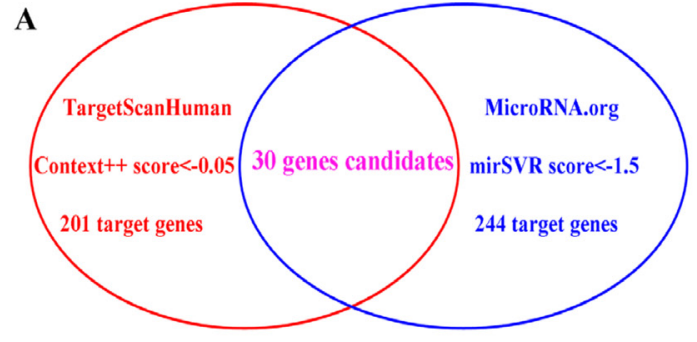

B

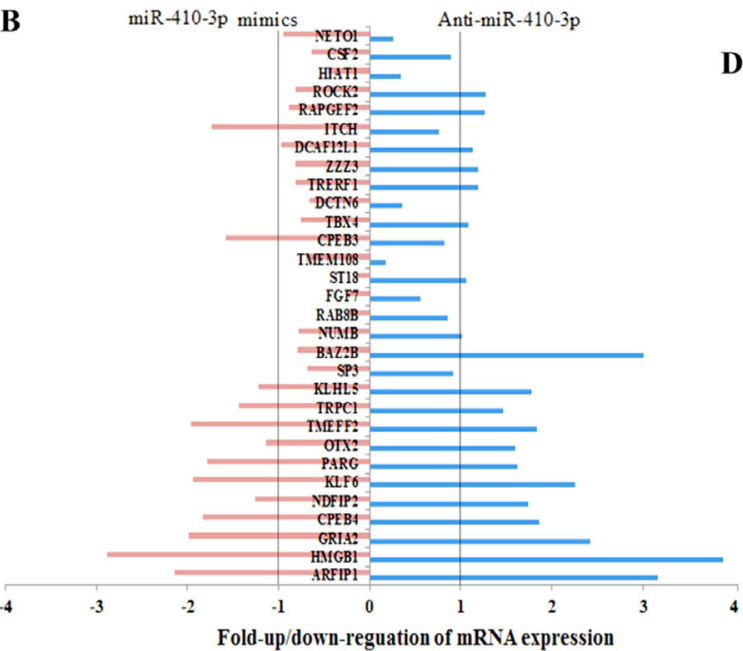

F

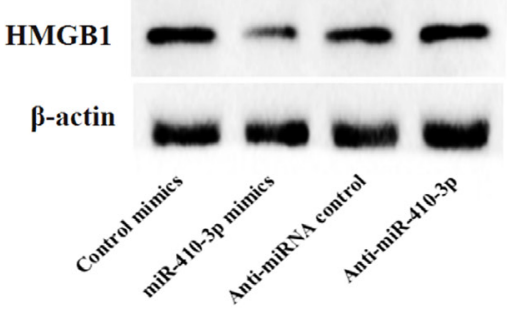

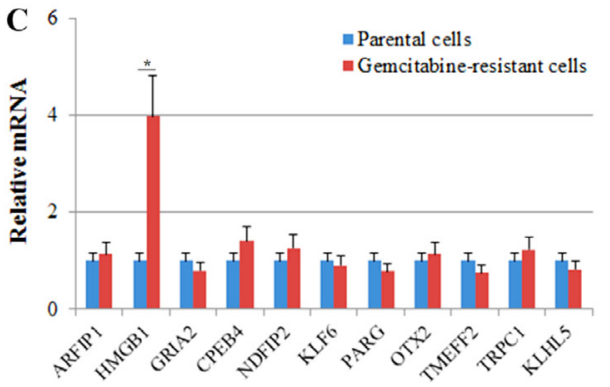
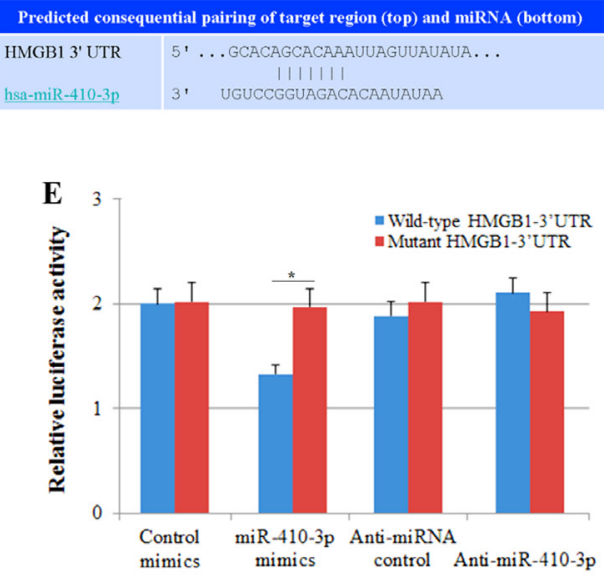

G

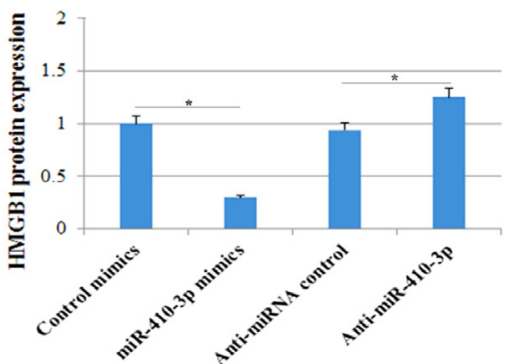

Figure 3: Predicting and validating the gene targets of miR-410-3p. (A) Online programs (TargetScanHuman 7.1 and MicroRNA.org) predicted putative gemcitabine resistance-related target genes of miR-410-3p. TargetScanHuman identified 201 target genes (Context++ score $<-0.05$ ), and MicroRNA.org identified 244 target genes (mirSVR score $<-1.5$ ). Thirty gene candidates were designated putative target genes of miR-410-3p by both programs. (B) The expression of the 30 putative target genes was determined by real-time PCR in human PDAC cells transfected with miR-410-3p mimics or anti-miR-410-3p. (C) The expression of 11 potential targets (ARFIP1, HMGB1, GRIA2, CPEB4, NDFIP2, KLF6, PARG, OTX2, TMEFF2, TRPC1 and KLHL5) was determined by real-time PCR in gemcitabine-resistant and parental clones of human PDAC cells. (D) Predicted miR-410-3p binding sites in the 3'-UTR of HMGB1. (E) Luciferase reporter assay with co-transfection of wild-type or mutant HMGB1 and miR-410-3p mimics, anti-miR-410-3p, mimicscontrol or anti-miRNA-control in human PDAC cells. (F, G) Western blot analysis of HMGB1 expression in gemcitabine-resistant clones of human PDAC cells transfected with miR-410-3p mimics, anti-miR-410-3p, mimics-control or anti-miRNA-control. All of the treatments in this figure were carried out in triplicate, and the results are displayed as the means $\pm \mathrm{SD} .{ }^{*} P<0.05$. 
Table 1: Predicted miR-410-3p targets \& target downregulation scores

\begin{tabular}{|c|c|c|c|c|c|c|}
\hline $\begin{array}{l}\text { Ortholog of } \\
\text { target gene }\end{array}$ & Gene name & $\begin{array}{c}\text { 3P-seq } \\
\text { tags }+5\end{array}$ & $\begin{array}{l}\text { mirSVR } \\
\text { score }\end{array}$ & $\begin{array}{c}\text { Cumulative } \\
\text { weighted } \\
\text { context++ score }\end{array}$ & $\begin{array}{c}\text { Total } \\
\text { context }++ \\
\text { score }\end{array}$ & $\begin{array}{c}\text { Previous } \\
\text { TargetScan } \\
\text { publication (s) }\end{array}$ \\
\hline BAZ2B & $\begin{array}{l}\text { bromodomain adjacent to zinc } \\
\text { finger domain, 2B }\end{array}$ & 25 & -3.84 & -0.11 & -0.13 & 2011 \\
\hline DCAF12L1 & $\begin{array}{l}\text { DDB1 and CUL4 associated } \\
\text { factor } 12 \text {-like } 1\end{array}$ & 5 & -3.15 & -0.23 & -0.23 & 2011 \\
\hline ARFIP1 & $\begin{array}{l}\text { ADP-ribosylation factor } \\
\text { interacting protein } 1\end{array}$ & 275 & -2.9 & -0.34 & -0.34 & \\
\hline HMGB1 & high mobility group box 1 & 800 & -2.64 & -0.25 & -0.32 & $2007,2009,2011$ \\
\hline GRIA2 & $\begin{array}{l}\text { glutamate receptor, } \\
\text { ionotropic, AMPA } 2\end{array}$ & 5 & -2.64 & -0.08 & -0.08 & $2007,2009,2011$ \\
\hline CPEB4 & $\begin{array}{l}\text { cytoplasmic polyadenylation } \\
\text { element binding protein } 4\end{array}$ & 472 & -2.55 & -0.09 & -0.09 & $2007,2009,2011$ \\
\hline ITCH & $\begin{array}{l}\text { itchy E3 ubiquitin protein } \\
\text { ligase }\end{array}$ & 769 & -2.42 & -0.11 & -0.13 & 2011 \\
\hline RAPGEF2 & $\begin{array}{l}\text { Rap guanine nucleotide } \\
\text { exchange factor (GEF) } 2\end{array}$ & 484 & -2.33 & -0.14 & -0.14 & 2009, 2011 \\
\hline ROCK2 & $\begin{array}{l}\text { Rho-associated, coiled-coil } \\
\text { containing protein kinase } 2\end{array}$ & 142 & -2.2 & -0.05 & -0.07 & \\
\hline NDFIP2 & $\begin{array}{l}\text { Nedd } 4 \text { family interacting } \\
\text { protein } 2\end{array}$ & 1747 & -2.01 & -0.18 & -0.3 & 2007,2011 \\
\hline ZZZ3 & $\begin{array}{l}\text { zinc finger, ZZ-type } \\
\text { containing } 3\end{array}$ & 338 & -2 & -0.3 & -0.42 & $2007,2009,2011$ \\
\hline KLF6 & Kruppel-like factor 6 & 4644 & -2 & -0.14 & -0.14 & 2011 \\
\hline PARG & $\begin{array}{l}\text { poly (ADP-ribose) } \\
\text { glycohydrolase }\end{array}$ & 445 & -1.99 & -0.15 & -0.21 & \\
\hline DCTN6 & dynactin 6 & 745 & -1.94 & -0.48 & -0.5 & 2009,2011 \\
\hline TRERF1 & $\begin{array}{l}\text { transcriptional regulating } \\
\text { factor } 1\end{array}$ & 52 & -1.93 & -0.07 & -0.07 & 2011 \\
\hline OTX2 & orthodenticle homeobox 2 & 5 & -1.92 & -0.28 & -0.28 & 2007,2011 \\
\hline CPEB3 & $\begin{array}{l}\text { cytoplasmic polyadenylation } \\
\text { element binding protein } 3\end{array}$ & 48 & -1.92 & -0.06 & -0.06 & $2007,2009,2011$ \\
\hline TBX4 & T-box 4 & 21 & -1.89 & -0.1 & -0.1 & \\
\hline TMEFF2 & $\begin{array}{l}\text { transmembrane protein with } \\
\text { EGF-like and two follistatin- } \\
\text { like domains } 2\end{array}$ & 179 & -1.84 & -0.13 & -0.39 & $2007,2009,2011$ \\
\hline TMEM108 & transmembrane protein 108 & 31 & -1.84 & -0.08 & -0.15 & 2011 \\
\hline TRPC1 & $\begin{array}{l}\text { transient receptor potential } \\
\text { cation channel, subfamily C, } \\
\text { member } 1\end{array}$ & 18 & -1.81 & -0.23 & -0.23 & 2009, 2011 \\
\hline SP3 & $\mathrm{Sp} 3$ transcription factor & 285 & -1.79 & -0.11 & -0.12 & $2007,2009,2011$ \\
\hline NUMB & numb homolog (Drosophila) & 2707 & -1.72 & -0.17 & -0.18 & $2007,2009,2011$ \\
\hline RAB8B & $\begin{array}{l}\text { RAB8B, member RAS } \\
\text { oncogene family }\end{array}$ & 45 & -1.7 & -0.07 & -0.09 & $2007,2009,2011$ \\
\hline FGF7 & fibroblast growth factor 7 & 5 & -1.68 & -0.09 & -0.09 & $2007,2009,2011$ \\
\hline ST18 & $\begin{array}{l}\text { suppression of tumorigenicity } \\
18 \text { (breast carcinoma) (zinc } \\
\text { finger protein) }\end{array}$ & 5 & -1.61 & -0.05 & -0.05 & $2007,2009,2011$ \\
\hline
\end{tabular}




\begin{tabular}{llccccc} 
KLHL5 & $\begin{array}{l}\text { kelch-like family member 5 } \\
\text { hippocampus abundant } \\
\text { HIAT1 }\end{array}$ & 366 & -1.59 & -0.12 & -0.18 & 2011 \\
transcript 1 & 1473 & -1.56 & -0.16 & -0.17 & 2007 \\
CSF2 & $\begin{array}{l}\text { colony stimulating factor 2 } \\
\text { (granulocyte-macrophage) }\end{array}$ & 103 & -1.51 & -0.16 & -0.16 & $2007,2009,2011$ \\
NETO1 & $\begin{array}{l}\text { neuropilin (NRP) and tolloid } \\
\text { (TLL)-like 1 }\end{array}$ & 5 & -1.5 & -0.21 & -0.24 & 2011 \\
\hline
\end{tabular}

\section{DISCUSSION}

Chemotherapy is the most common treatment option for many cancers, including pancreatic cancer. However, it offers little therapeutic value in many cases due to the rapid development of chemoresistance. Recently, several studies have indicated that some miRNAs [34], such as miR-21 [35], miR-155 [36], miR-320c [18] and miR-1246 [37], have been involved in the induction of chemoresistance in PDAC. The identification of key miRNA networks in pancreatic cancer will provide long-awaited diagnostic, therapeutic, and prognostic tools for early detection, better treatment options, extended life expectancy, and better quality of life in PDAC patients [38]. Thus, we identified potential miRNAs related to gemcitabine resistance in a human pancreatic cancer xenograft (HPCx) with miRNA microarray analysis and showed that miR-34-5p, miR-410$3 p$, miR-449-5p and miR-203 were significantly downregulated in HPCx tumor tissues from gemcitabine-treated mice. In addition, we found that low miR-410-3p expression correlated with gemcitabine resistance and poorer prognosis in human PDAC.

The most widely used chemotherapeutic treatment for pancreatic cancer is gemcitabine, which shows a moderate tumor suppression response rate of $\sim 12 \%$ [18]. Therefore, intense research efforts are required to improve the outcome for successful pancreatic cancer treatment. Studies in vitro and in vivo have demonstrated the tremendous efficacy of miRNA as a therapeutic tool in the chemoresistance of PDAC to gemcitabine by regulating chemoresistance-related miRNAs. Downregulation of miR-21 [20] and miR-125a [21] enhanced gemcitabine sensitivity in human pancreatic cancer cells. Up-regulation of miR-33a [22, 23], miRNA-181b [24] and miR-211 [25] increased the sensitivity of PDAC cells to gemcitabine in vitro and in nude mice. Evidence has shown that miR-410-3p acts as an oncogene or tumorsuppressor gene in various types of cancer, including cholangiocarcinoma [39], colorectal cancer [40], breast cancer [41] and pancreatic cancer [42]. Re-expression of miR-410 enhanced the sensitivity of adjuvant radiotherapy in gastric cancer cells [43]. Here, we identified miR-410$3 p$ as a potential therapeutic target of chemoresistance to gemcitabine in PDAC. The in vitro MTT assay and FCM apoptosis assay after up-regulation of miR$410-3 p$ in PDAC cells suggested that miR-410-3p up- regulation is sufficient to enhance the growth-inhibitory effects and apoptosis caused by gemcitabine treatment. Overexpression of miR-410-3p promoted the reduction in the volume, weight, and apoptosis of HPCx tumor tissues caused by gemcitabine treatment in vivo. Our result is consistent with some reports that have identified miR-410$3 p$ as a potential therapeutic target of chemoresistance to gemcitabine in PDAC.

A better understanding of disease pathogenesis mechanisms will facilitate the early detection and development of effective treatments. We used online programs to search for the potential targets of miR-410-3p and found that HMGB1 was significantly affected by both up- and down-regulation of miR-410-3p expression and expressed in gemcitabine-resistant PDAC cells. Moreover, a luciferase assay confirmed that miR-410-3p can directly target the $3^{\prime}$-UTR sequences of HMGB1. Consistent with the dual luciferase assay, ChIP analysis also observed the direct interaction between miR-410-3p and HMGB1 (Supplementary Figure 3A). In addition, up/ down-regulation of miR-410-3p expression by transfection with miR-410-3p mimics or anti-miR-410-3p did not affect the expression of HMGB2, HMGB3 or HMGB4 in human PDAC cells (Supplementary Figure 3B). HMGB1, known primarily as a regulator of autophagy, is expressed in various normal cells and has also been confirmed to be involved in cancer development by interfering with several signaling pathways $[44,45]$. Recently, studies have suggested that HMGB1 binds to the autophagy regulator Beclin1 and regulates the formation of the Beclin1PI3KC3 complex that facilitates autophagic progression [31]. Induction of autophagy by HMGB1 is important for tumor development and a novel target for cancer therapy $[31,46]$. Autophagy is a natural destructive mechanism of cells and is characterized as a degrading and recycling of cellular components for new cell formation [27]. Tumor cells use cytoprotective autophagy as a defense against apoptosis cell death, which in turn contributes to the development of chemoresistance. There is mounting evidence that autophagy contributes to increased gemcitabine resistance in PDAC cancer [28, 47, 48].

Some studies have also reported that miRNAs can modulate chemotherapy via autophagy [49, 50]. MicroRNA-410 enhances chemosensitivity via regulation of autophagy-related genes [51]. However, the regulatory mechanisms by which miR-410-3p effects chemoresistance 
A
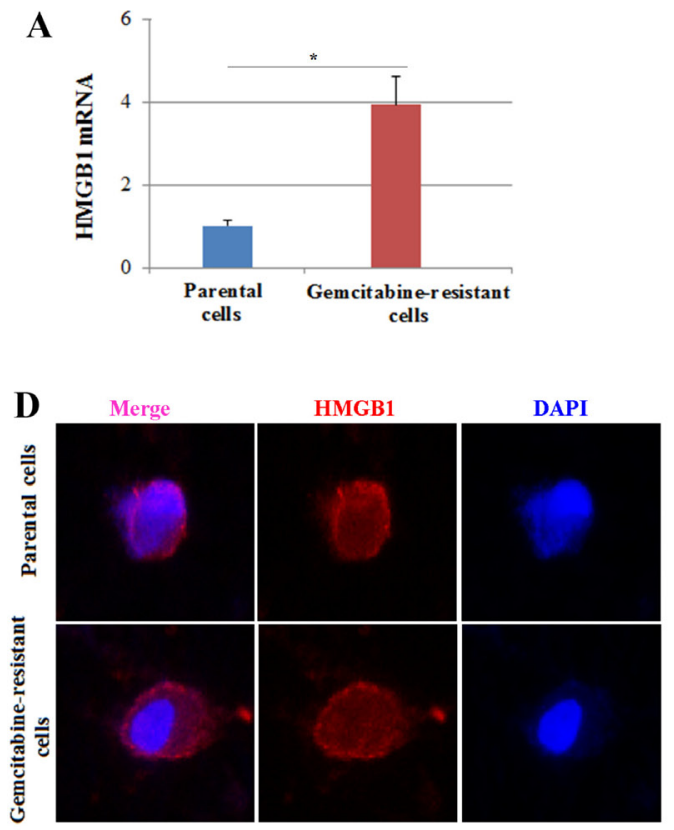

B

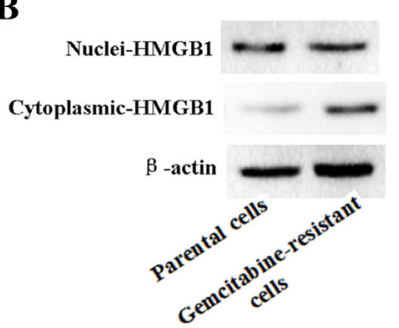

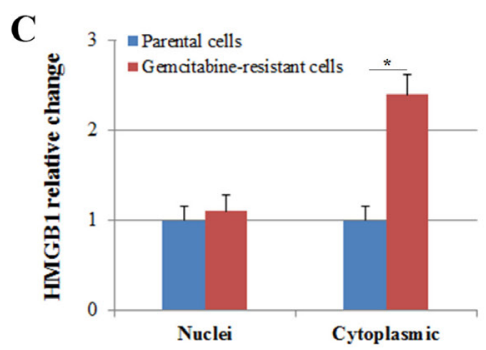
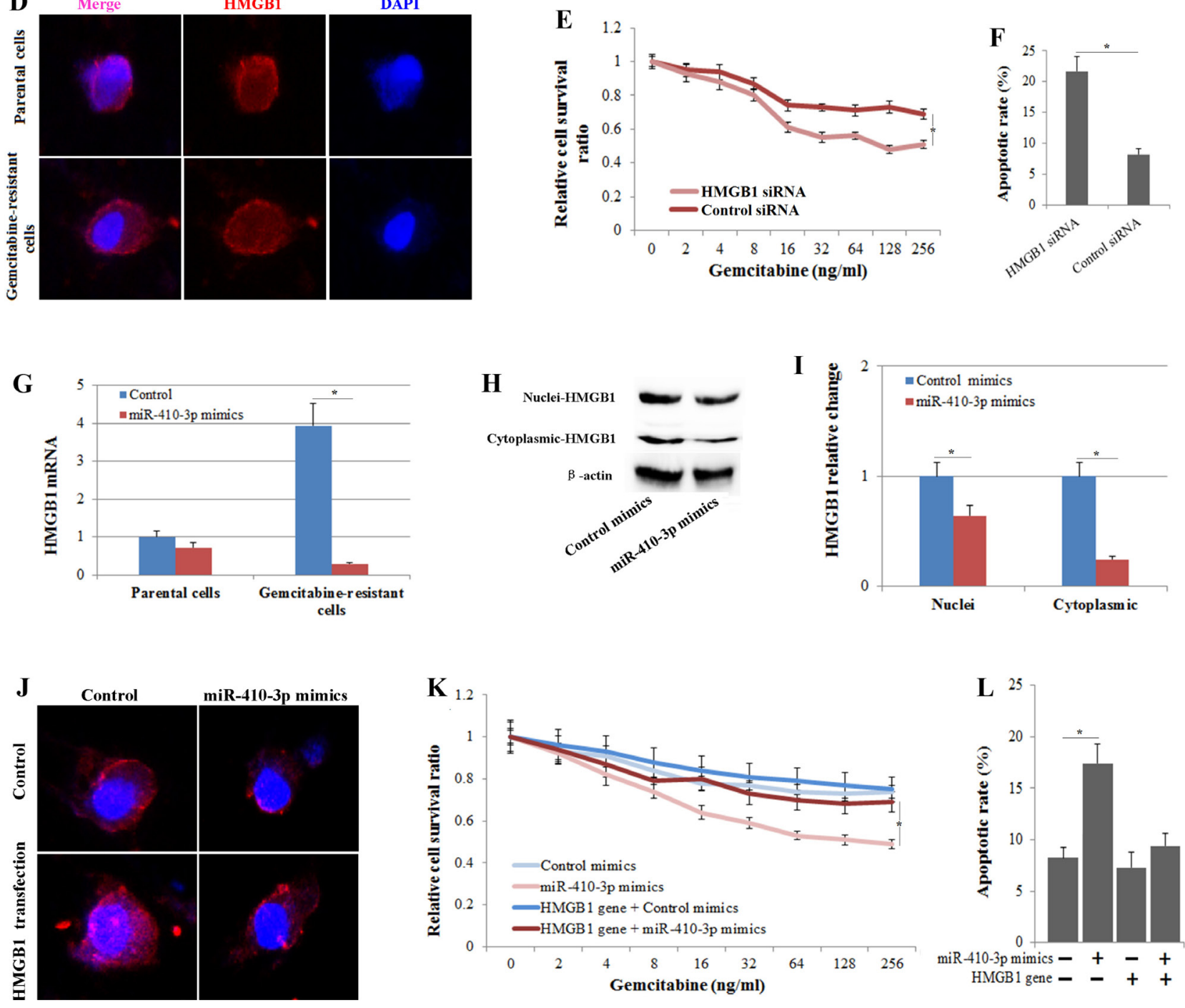

Figure 4: The expression and translocation of HMGB1 correlates with gemcitabine resistance in human PDAC cells. HMGB1 expression was determined by real-time PCR (A), Western blot (B) and immunofluorescence (D) in gemcitabine-resistant and parental clones of human PDAC cells. (C) The relative change in nuclear and cytoplasmic HMGB1 expression was quantified in gemcitabine-resistant clones of human PDAC cells relative to that in parental clones. Growth-inhibitory effects (E) and the apoptotic rate (annexin V/PI double-positive cells) (F) of gemcitabine on gemcitabine-resistant PDAC cells treated with or without HMGB1 siRNA were assessed by MTT assay and FCM assay, respectively. (G) HMGB1 expression was determined by real-time PCR in gemcitabine-resistant and parental clones of human PDAC cells treated with or without miR-410-3p mimics. HMGB1 expression was determined by Western blot $(\mathbf{H})$ and immunofluorescence $(\mathbf{J})$ in gemcitabine-resistant clones of human PDAC cells treated with or without miR-410-3p mimics and/ or HMGB1 gene transfection. The relative change in nuclear and cytoplasmic HMGB1 expression (I) was quantified relative to that in clones treated with mimics-control. Growth-inhibitory effects (K) and the apoptotic rate (annexin V/PI double-positive cells) (L) of gemcitabine on gemcitabine-resistant PDAC cells treated with or without miR-410-3p mimics and/or HMGB1 gene transfection were assessed by MTT assay and FCM assay, respectively. All of the treatments in this figure were carried out in triplicate, and the results are displayed as the means $\pm \mathrm{SD} .{ }^{*} P<0.05$. 
A

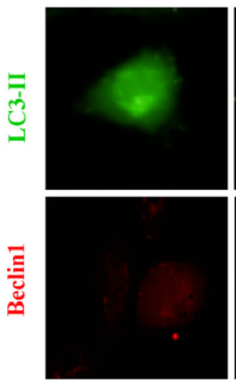

Gemcitabine HMGB1 siRNA -

$\mathrm{C}$

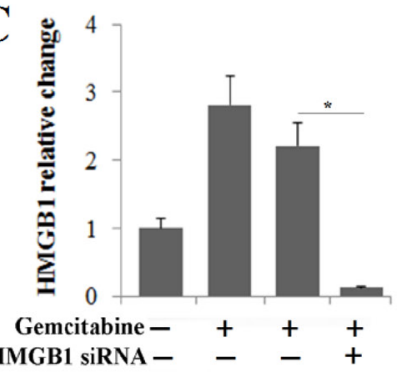

$\mathbf{F}$
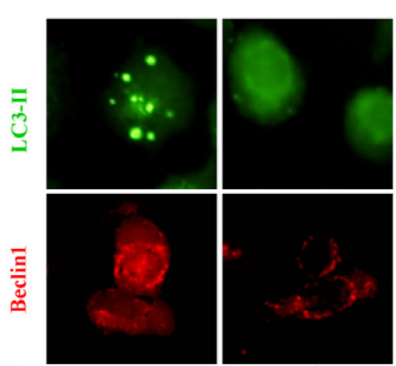

Gemcitabine +
miR-410-3p mimics anti-miR-410-3p -

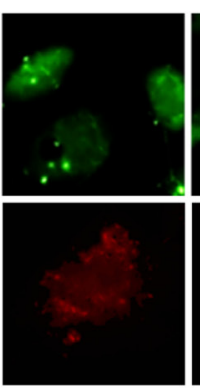

$+$

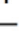

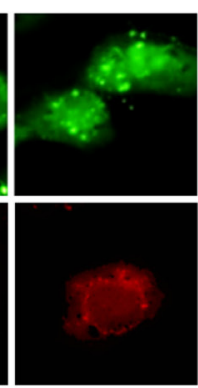

$+$

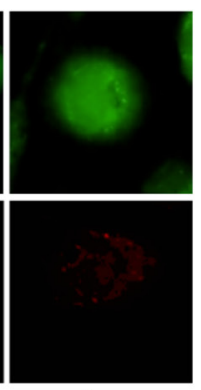

+
+

B
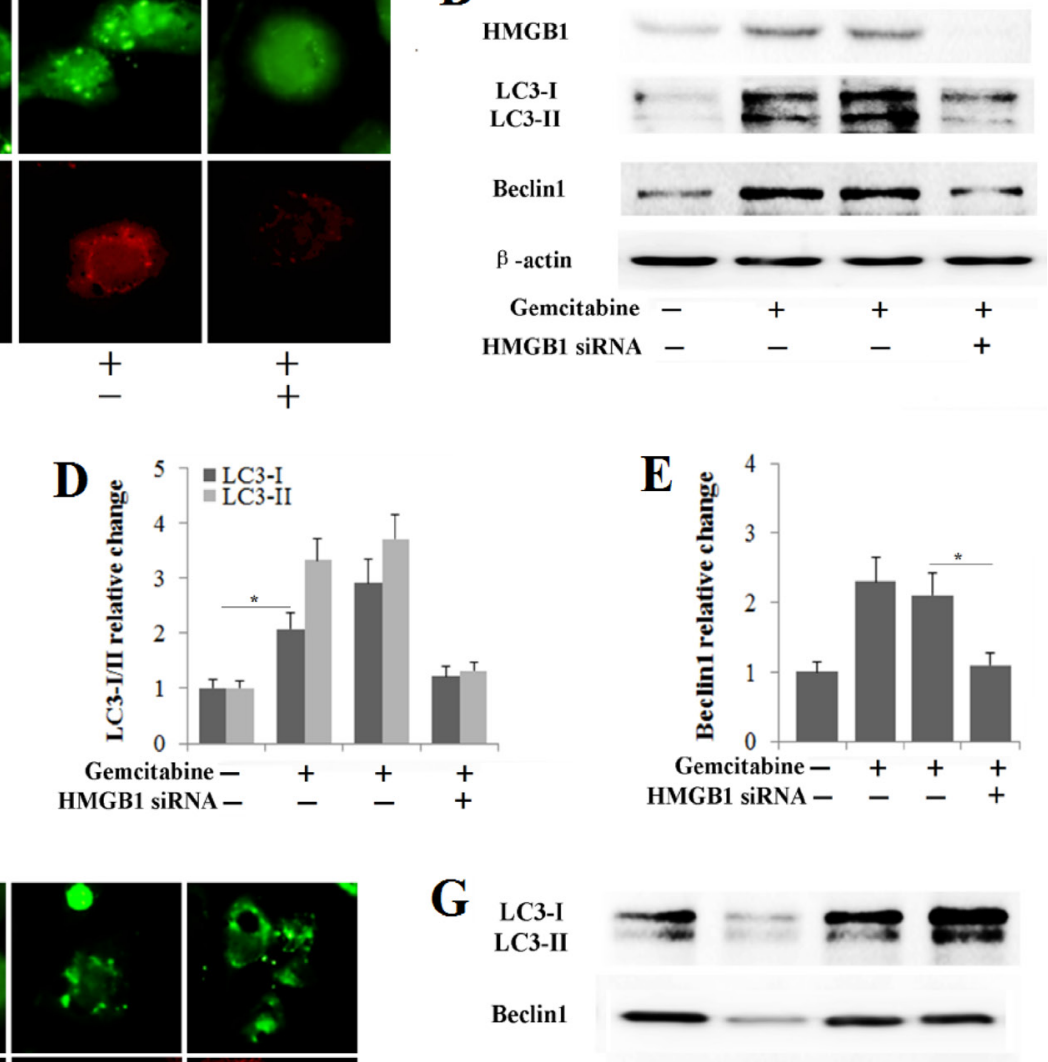

G
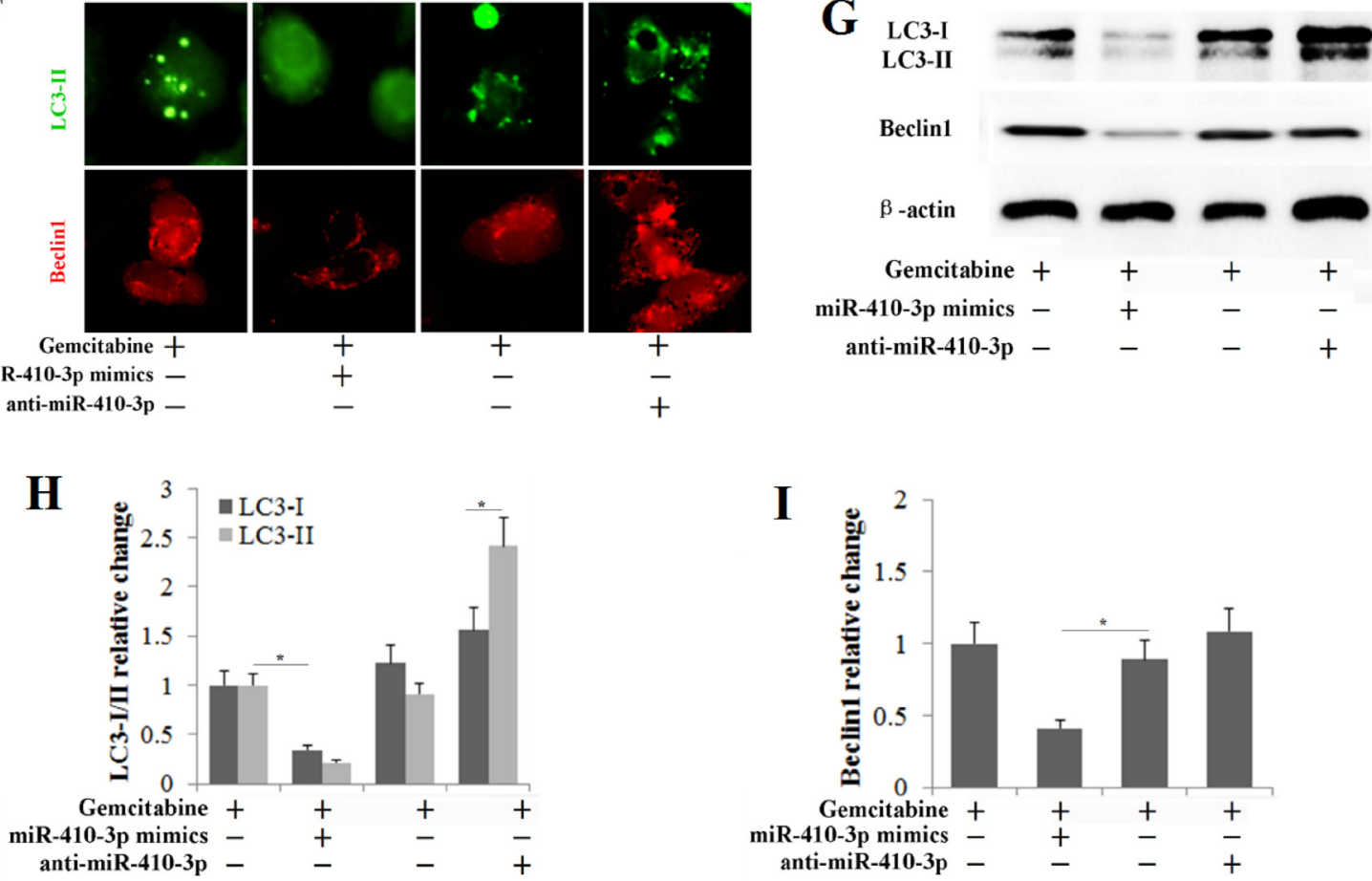

Figure 5: miR-410-3p inhibits HMGB1-mediated autophagy in human PDAC cells during chemotherapy. (A) Human PDAC cells that stably express GFP-LC3 were used to detect autophagy (Tip), and immunofluorescence was used to determine Beclin1 expression (Sif) after the PDAC cells were treated with or without $50 \mathrm{ng} / \mathrm{ml}$ gemcitabine and/or HMGB1 siRNA. (B) HMGB1, LC3 and Beclin1 expression levels were determined by Western blot in gemcitabine-resistant PDAC cells treated with or without $50 \mathrm{ng} / \mathrm{ml}$ gemcitabine and/or HMGB1 siRNA. The relative change in HMGB1 (C), LC3-I/II (D) and Beclin1 (E) was quantified relative to that in untreated controls. (F) Human PDAC cells that stably express GFP-LC3 were used to detect autophagy (Tip), and immunofluorescence was used to determine Beclin1 expression (Sif) after the gemcitabine-resistant cells were treated with $50 \mathrm{ng} / \mathrm{ml}$ gemcitabine and/or miR-410-3p mimics or anti-miR-410-3p. (G) LC3 and Beclin1 expression levels were determined by Western blot in gemcitabine-resistant PDAC cells treated with $50 \mathrm{ng} / \mathrm{ml}$ gemcitabine and/or miR-410-3p mimics or anti-miR-410-3p. The change in LC3-I/II (H) and Beclin1 (I) expression was quantified relative to that in gemcitabine-treated controls. All of the treatments in this figure were carried out in triplicate, and the results are displayed as the means $\pm \mathrm{SD} .{ }^{*} P<0.05$. 
of PDAC to gemcitabine remain largely unknown. The present study revealed that miR-410-3p attenuated gemcitabine resistance in PDAC cancer cells by targeting the 3'UTR of HMGB1. HMGB1-mediated autophagy during chemotherapy in PDAC cells was further confirmed by autophagy-related biomarker assays. Autophagy was inhibited after transfection of PDAC cells with HMGB1 siRNA or miR-410-3p mimics during chemotherapy. Further investigations indicated that cell viability was significantly decreased and apoptosis was significantly increased in the gemcitabine-treated PDAC cells transfected with miR-410-3p mimics. Conversely, miR410-3p silencing was able to effectively induce autophagic activation, promote cell growth and suppress cell apoptosis in the gemcitabine-treated PDAC cells. Taken together, our results of the present study provided novel evidence suggesting that miR-410-3p attenuates chemoresistance of PDAC to gemcitabine by inhibiting HMGB1-induced autophagy.

In summary, by using miRNA microarray and RTPCR analysis, we demonstrated that miR-410-3p was down-regulated in HPCx tumor tissues from gemcitabinetreated mice and found that low miR-410-3p expression was associated with gemcitabine resistance in HPCX tumors and PDAC cells as well as poor prognosis in PDAC patients. On the other hand, both in vivo and in vitro, our study demonstrated that overexpression of miR-410-3p attenuated gemcitabine resistance of PDAC by targeting the 3'-UTR sequences of HMGB1 and inhibiting HMGB1-mediated autophagy. Together, our studies suggest that miR-410-3p expression may be a useful indicator of the potential for chemoresistance to gemcitabine and provide a potential new therapeutic target for chemoresistance in PDAC.

\section{MATERIALS AND METHODS}

\section{Cell culture and treatment}

Human PDAC cell lines (MiaPaCa2 and PANC1, Shanghai Cell Bank, China) were cultured in DMEM medium [23] (Invitrogen, CA) supplemented with 10\% fetal bovine serum, $0.5 \mathrm{mM}$ sodium pyruvate (Sigma-Aldrich, Steinheim, Germany), 50 units $/ \mathrm{ml}$ penicillin, and $50 \mu \mathrm{g} / \mathrm{ml}$ streptomycin. The cells were maintained in a 5\% CO2humidified atmosphere at $37^{\circ} \mathrm{C}$. Gemcitabine-resistant cells were generated by exposure to gradually increasing concentrations of the drug for 2 months. Parental $\mathrm{MiaPaCa} 2$ cells were exposed to gemcitabine (Eli Lilly Pharmaceuticals, Indianapolis, USA) at an initial concentration of $1 \mathrm{ng} / \mathrm{ml}$. When cells adapted to the drug, the gemcitabine concentration was gradually increased to the final concentrations $(20 \mathrm{ng} / \mathrm{ml})$.

Cells were transfected with miR-410-3p mimics or miRNA scrambled controls at a final concentration of 20 $\mathrm{nM}$ using Oligofectamine (Invitrogen), or the antisense oligonucleotide inhibitor of hsa-miR-155 (anti-miR-410-3p) or their scrambled oligonucleotides (anti-miRNA control) at a final concentration of $200 \mathrm{nM}$ using the DharmaFECT3 transfection reagent (Dharmacon), or with the empty vector pEGFP-N1 or the human pEGFP-N1-HMGB1 vector using the ExGen-500 transfection reagent (Fermentas, Germany), or with $100 \mathrm{nmol} / \mathrm{l}$ human HMGB1 small interfering (si) RNA or a control siRNA (Santa Cruz) using RNAi MAX transfection reagent. In apoptosis experiments, the PDAC cells treated with $50 \mathrm{ng} / \mathrm{ml}$ gemcitabine or PBS for $72 \mathrm{~h}$ before flow cytometry assay.

Growth inhibition assay and the dual-parameter (PI/ Annexin V) flow cytometry were performed to detect the cell viability and apoptosis. Real-time PCR was used to detect the expression levels of miR-34-5p, miR-410-3p, miR-449-5p, miR-203, HMGB1, ARFIP1, GRIA2, CPEB4, NDFIP2, KLF6, PARG, OTX2, TMEFF2, TRPC1 and KLHL5. Western blotting was used to detect the expression of HMGB1, LC3 and Beclin1. Immunofluorescence staining was performed to detect the expression of HMGB1 and Beclin1.

\section{In vivo experiments}

This study was approved by the Animal Experiments Committee, West China Hospital, Sichuan University. It was performed in accordance with the National Institutes of Health guidelines for the use of experimental animals. Six-week-old female nude mice were purchased from Dossy Biological Technology Co. Ltd. (Chengdu, China), and maintained in a specific pathogen-free environment. For the human pancreatic cancer xenografts (HPCx), MiaPaCa2 or PANC-1 cells $\left(1 \times 10^{6}\right)$ were subcutaneously transplanted into the interscapular fat pad of female nude mice under anesthesia. The mice were administered gemcitabine $(125 \mathrm{mg} / \mathrm{kg})$ intraperitoneally three times on days 17,24 , and 31 after xenograft transplantation. Subcutaneous tumor volume was calculated as follows: (greatest diameter) $\times(\text { shortest diameter })^{2} \times 0.5$. Gemcitabine therapy was initiated when the tumor volume was $80 \sim 100 \mathrm{~mm}^{3}$. Mice were euthanized on day 41 . The tumor tissue sections were stained with hematoxylin and eosin; alternatively, a TUNEL assay was performed on the sections using an in situ cell death detection kit (Roche Diagnostics). MicroRNAs were identified by miRNA microarray analysis (Agilent Technologies) in tumor tissues from treated mice with gemcitabine relative to from controls mice.

\section{Clinical samples and data}

86 PDAC in patients who received gemcitabine chemotherapy after radical surgical resection were collected between July 2010 and March 2014 at the West China Hospital of Sichuan University. Gemcitabine chemotherapy was started within 8 weeks postresection. Gemcitabine (intravenous infusion of $1000 \mathrm{mg} / \mathrm{m}^{2}$ ) was given on days 1,8 , and 15 of each cycle, to be repeated every 4 weeks. This lasted 
for 6 months. Written informed consent was obtained from all patients involved, and the PDAC diagnosis was based on hematoxylin eosin and immunohistochemical staining from tumor tissue sections. None of the patients received any other preoperative and postoperative chemotherapy or radiotherapy. The clinical data were collected from each patient, including age, gender, location, tumor size and lymph node metastasis, degree of differentiation, pT category, the presence of metastatic disease, and survival. Our study received approval from Institutional Review Board of Sichuan University West China Hospital. Patients were followed up till the end of April 2017, either in the form of telephonic conversation or as outpatient clinic appointment. Real-time PCR was used to detect the expression levels of miR-410-3p in clinical PDAC samples.

\section{Statistical analysis}

The results presented are the average of at least three experiments, each performed in triplicate with standard errors. Kruskal-Wallis $\mathrm{H}$ test and Chi-square test were used to analyse the expression rate in all groups. A Kaplan-Meier survival analysis was performed to assess the OS and DFS of the patients. One-way analysis of variance (ANOVA) was used to analyze the differences between groups. Statistical analyses were conducted by SPSS 20.0, and a $P$-value less than 0.05 was considered to be statistically significant.

Supplemental Information includes Extended Experimental Procedures

\section{CONFLICTS OF INTEREST}

No potential conflicts of interest relevant to this article were reported.

\section{REFERENCES}

1. Siegel R, Ma J, Zou Z, Jemal A. Cancer statistics, 2014. CA Cancer J Clin. 2014; 64:9-29.

2. Li D, Xie K, Wolff R, Abbruzzese JL. Pancreatic cancer. Lancet. 2004; 363:1049-57.

3. Oettle H, Post S, Neuhaus P, Gellert K, Langrehr J, Ridwelski K, Schramm H, Fahlke J, Zuelke C, Burkart C, Gutberlet K, Kettner E, Schmalenberg H, et al. Adjuvant chemotherapy with gemcitabine vs observation in patients undergoing curative-intentresection of pancreatic cancer: a randomized controlled trial. JAMA. 2007; 297:267-77.

4. Ueno H, Kosuge T, Matsuyama Y, Yamamoto J, Nakao A, Egawa S, Doi R, Monden M, Hatori T, Tanaka M, Shimada M, Kanemitsu K. A randomised phase III trial comparing gemcitabine with surgery-only in patients with resectedpancreatic cancer: Japanese Study Group of Adjuvant Therapy for Pancreatic Cancer. Br J Cancer. 2009; 101:908-15. https://doi.org/10.1038/sj.bjc.6605256.
5. Neoptolemos JP, Stocken DD, Bassi C, Ghaneh P, Cunningham D, Goldstein D, Padbury R, Moore MJ, Gallinger S, Mariette C, Wente MN, Izbicki JR, Friess H, et al. European Study Group for Pancreatic Cancer. Adjuvant chemotherapy with fluorouracil plus folinic acid vs gemcitabine following pancreatic cancer resection: a randomized controlled trial. JAMA. 2010; 304:1073-81. https://doi.org/10.1001/jama.2010.1275.

6. Burris HA 3rd, Moore MJ, Andersen J, Green MR, Rothenberg ML, Modiano MR, Cripps MC, Portenoy RK, Storniolo AM, Tarassoff P, Nelson R, Dorr FA, Stephens $\mathrm{CD}$, et al. Improvements in survival and clinical benefit with gemcitabine as first-line therapy for patientswith advanced pancreas cancer: a randomized trial. J Clin Oncol. 1997; 15:2403-13.

7. Galasso M, Sandhu SK, Volinia S. MicroRNA expression signatures in solid malignancies. Cancer J. 2012; 18:23843. https://doi.org/10.1097/PPO.0b013e318258b5f4.

8. Zhang B, Pan X, Cobb GP, Anderson TA. microRNAs as oncogenes and tumor suppressors. Dev Biol. 2007; 302:1-12.

9. Sun L, Chua CY, Tian W, Zhang Z, Chiao PJ, Zhang W. MicroRNA Signaling Pathway Network in Pancreatic Ductal Adenocarcinoma. J Genet Genomics. 2015; 42:563-77. https://doi.org/10.1016/j.jgg.2015.07.003.

10. Sassen S, Miska EA, Caldas C. MicroRNA: implications for cancer. Virchows Arch. 2008; 452:1-10.

11. Zhang XJ, Ye H, Zeng CW, He B, Zhang H, Chen YQ. Dysregulation of miR-15a and miR-214 in human pancreatic cancer. J Hematol Oncol. 2010; 3:46. https://doi. org/10.1186/1756-8722-3-46.

12. Ali S, Ahmad A, Banerjee S, Padhye S, Dominiak K, Schaffert JM, Wang Z, Philip PA, Sarkar FH. Gemcitabine sensitivity can be induced in pancreatic cancer cells through modulation of miR-200and miR-21 expression by curcumin or its analogue CDF. Cancer Res. 2010; 70:3606-17. https://doi. org/10.1158/0008-5472.CAN-09-4598.

13. Giovannetti E, Funel N, Peters GJ, Del Chiaro M, Erozenci LA, Vasile E, Leon LG, Pollina LE, Groen A, Falcone A, Danesi R, Campani D, Verheul HM, et al. MicroRNA-21 in pancreatic cancer: correlation with clinical outcome and pharmacologic aspectsunderlying its role in the modulation of gemcitabine activity. Cancer Res. 2010; 70:4528-38. https://doi.org/10.1158/0008-5472. CAN-09-4467.

14. Ji Q, Hao X, Zhang M, Tang W, Yang M, Li L, Xiang D, Desano JT, Bommer GT, Fan D, Fearon ER, Lawrence TS, $\mathrm{Xu}$ L. MicroRNA miR-34 inhibits human pancreatic cancer tumor-initiating cells. PLoS One. 2009; 4:e6816. https://doi. org/10.1371/journal.pone.0006816.

15. Li Y, VandenBoom TG 2nd, Kong D, Wang Z, Ali S, Philip PA, Sarkar FH. Up-regulation of miR-200 and let-7 by natural agents leads to the reversal of epithelial-tomesenchymal transition in gemcitabine-resistant pancreatic 
cancer cells. Cancer Res. 2009; 69:6704-12. https://doi. org/10.1158/0008-5472.CAN-09-1298.

16. Park JK, Lee EJ, Esau C, Schmittgen TD. Antisense inhibition of microRNA-21 or -221 arrests cell cycle, induces apoptosis, and sensitizesthe effects of gemcitabine in pancreatic adenocarcinoma. Pancreas. 2009; 38:e190-9. https://doi.org/10.1097/MPA.0b013e3181ba82e1.

17. Iwagami $Y$, Eguchi H, Nagano H, Akita H, Hama N, Wada H, Kawamoto K, Kobayashi S, Tomokuni A, Tomimaru Y, Mori M, Doki Y. miR-320c regulates gemcitabine-resistance in pancreatic cancer via SMARCC1. Br J Cancer. 2013; 109:502-11. https://doi.org/10.1038/ bjc.2013.320.

18. Papaconstantinou IG, Lykoudis PM, Gazouli M, Manta A, Polymeneas G, Voros D. A review on the role of microRNA in biology, diagnosis, and treatment of pancreaticadenocarcinoma. Pancreas. 2012; 41:671-7. https://doi.org/10.1097/MPA.0b013e31823c9d21.

19. Keklikoglou I, Hosaka K, Bender C, Bott A, Koerner C, Mitra D, Will R, Woerner A, Muenstermann E, Wilhelm H, Cao Y, Wiemann S. MicroRNA-206 functions as a pleiotropic modulator of cell proliferation, invasion andlymphangiogenesis in pancreatic adenocarcinoma by targeting ANXA2 and KRAS genes. Oncogene. 2015; 34:4867-78. https://doi.org/10.1038/ onc.2014.408.

20. Paik WH, Kim HR, Park JK, Song BJ, Lee SH, Hwang JH. Chemosensitivity induced by down-regulation of microRNA-21 in gemcitabine-resistantpancreatic cancer cells by indole-3-carbinol. Anticancer Res. 2013; 33:1473-81.

21. Yao J, Li Z, Wang X, Xu P, Zhao L, Qian J. MiR-125a regulates chemo-sensitivity to gemcitabine in human pancreatic cancer cells throughtargeting A20. Acta Biochim Biophys Sin (Shanghai). 2016; 48:202-8. https://doi. org/10.1093/abbs/gmv129.

22. Liang C, Wang Z, Li YY, Yu BH, Zhang F, Li HY. miR-33a suppresses the nuclear translocation of $\beta$-catenin to enhance gemcitabine sensitivity in human pancreatic cancer cells. Tumour Biol. 2015; 36:9395-403. https://doi.org/10.1007/ s13277-015-3679-5.

23. Liang C, Yu XJ, Guo XZ, Sun MH, Wang Z, Song Y, Ni QX, Li HY, Mukaida N, Li YY. MicroRNA-33amediated downregulation of Pim-3 kinase expression renders human pancreatic cancer cells sensitivity to gemcitabine. Oncotarget. 2015; 6:14440-55. http://doi. org/10.18632/oncotarget.3885.

24. Cai B, An Y, Lv N, Chen J, Tu M, Sun J, Wu P, Wei J, Jiang K, Miao Y. miRNA-181b increases the sensitivity of pancreatic ductal adenocarcinoma cells to gemcitabine in vitro and in nude mice by targeting BCL-2. Oncol Rep. 2013; 29:1769-76. https://doi.org/10.3892/or.2013.2297.

25. Maftouh M, Avan A, Funel N, Frampton AE, Fiuji H, Pelliccioni S, Castellano L, Galla V, Peters GJ, Giovannetti E. miR-211 modulates gemcitabine activity through downregulation of ribonucleotide reductase and inhibits the invasive behavior of pancreatic cancer cells.
Nucleosides Nucleotides Nucleic Acids. 2014; 33:384-93. https://doi.org/10.1080/15257770.2014.891741.

26. Yin H, Yang X, Gu W, Liu Y, Li X, Huang X, Zhu X, Tao Y, Gou X, He W. HMGB1-mediated autophagy attenuates gemcitabine-induced apoptosis in bladder cancer cells involving JNK and ERK activation. Oncotarget. 2017; 8:71642-71656. https://doi.org/10.18632/oncotarget.17796.

27. Buyuklu M, Kandemir FM, Ozkaraca M, Set T, Bakirci EM, Topal E. Protective effect of curcumin against contrast induced nephropathy in rat kidney: what ishappening to oxidative stress, inflammation, autophagy and apoptosis? Eur Rev Med Pharmacol Sci. 2014;18:461-70.

28. Ropolo A, Bagnes CI, Molejon MI, Lo Re A, Boggio V, Gonzalez CD, Vaccaro MI. Chemotherapy and autophagymediated cell death in pancreatic cancer cells. Pancreatology. 2012; 12:1-7. https://doi.org/10.1016/j.pan.2011.11.003.

29. Ojha R, Jha V, Singh SK. Gemcitabine and mitomycin induced autophagy regulates cancer stem cell pool in urothelial carcinoma cells. Biochim Biophys Acta. 2016; 1863:347-59. https://doi.org/10.1016/j.bbamcr.2015.12.002.

30. Chen YM, Liu Y, Wei HY, Lv KZ, Fu PF. Large intergenic noncoding RNA-ROR reverses gemcitabine-induced autophagy and apoptosisin breast cancer cells. Oncotarget. 2016; 7:59604-59617. https://doi.org/10.18632/oncotarget.10730.

31. Huang J, Ni J, Liu K, Yu Y, Xie M, Kang R, Vernon P, Cao L, Tang D. HMGB1 promotes drug resistance in osteosarcoma. Cancer Res. 2012; 72:230-8. https://doi. org/10.1158/0008-5472.CAN-11-2001.

32. Huang J, Liu K, Yu Y, Xie M, Kang R, Vernon P, Cao L, Tang D, Ni J. Targeting HMGB1-mediated autophagy as a novel therapeutic strategy for osteosarcoma. Autophagy. 2012; 8:275-7. https://doi.org/10.4161/auto.8.2.18940.

33. Kang R, Livesey KM, Zeh HJ 3rd, Lotze MT, Tang D. Metabolic regulation by HMGB1-mediated autophagy and mitophagy. Autophagy. 2011; 7:1256-8. https://doi. org/10.4161/auto.7.10.16753.

34. Frampton AE, Krell J, Jacob J, Stebbing J, Jiao LR, Castellano L. microRNAs as markers of survival and chemoresistance in pancreatic ductal adenocarcinoma. Expert Rev Anticancer Ther. 2011; 11:1837-42. https://doi. org/10.1586/era.11.184.

35. Paik WH, Kim HR, Park JK, Song BJ, Lee SH, Hwang JH. Chemosensitivity induced by down-regulation of microRNA-21 in gemcitabine-resistantpancreatic cancer cells by indole-3-carbinol. Anticancer Res. 2013; 33:1473-81.

36. Mikamori M, Yamada D, Eguchi H, Hasegawa S, Kishimoto T, Tomimaru Y, Asaoka T, Noda T, Wada H, Kawamoto K, Gotoh K, Takeda Y, Tanemura M, et al. MicroRNA-155 Controls Exosome Synthesis and Promotes Gemcitabine Resistance in Pancreatic Ductal Adenocarcinoma. Sci Rep. 2017; 7:42339. https://doi. org/10.1038/srep42339.

37. Hasegawa S, Eguchi H, Nagano H, Konno M, Tomimaru Y, Wada H, Hama N, Kawamoto K, Kobayashi S, 
Nishida N, Koseki J, Nishimura T,Gotoh N, et al. MicroRNA-1246 expression associated with CCNG2mediated chemoresistance and stemness inpancreatic cancer. Br J Cancer. 2014; 111:1572-80. https://doi. org/10.1038/bjc.2014.454.

38. Subramani R, Gangwani L, Nandy SB, Arumugam A, Chattopadhyay M, Lakshmanaswamy R. Emerging roles of microRNAs in pancreatic cancer diagnosis, therapy and prognosis (Review). Int J Oncol. 2015; 47:1203-10. https:// doi.org/10.3892/ijo.2015.3129.

39. Palumbo T, Poultsides GA, Kouraklis G, Liakakos T, Drakaki A, Peros G, Hatziapostolou M, Iliopoulos D. A functional microRNA library screen reveals miR-410 as a novel anti-apoptotic regulator of cholangiocarcinoma. BMC Cancer. 2016; 16:353.

40. Liu C, Zhang A, Cheng L, Gao Y. miR-410 regulates apoptosis by targeting Bak1 in human colorectal cancer cells. Mol Med Rep. 2016; 14:467-73. https://doi. org/10.3892/mmr.2016.5271.

41. Zhang YF, Yu Y, Song WZ, Zhang RM, Jin S, Bai JW, Kang HB, Wang X, Cao XC. miR-410-3p suppresses breast cancer progression by targeting Snail. Oncol Rep. 2016; 36:480-6. https://doi.org/10.3892/or.2016.4828.

42. Guo R, Gu J, Zhang Z, Wang Y, Gu C. MicroRNA-410 functions as a tumor suppressor by targeting angiotensin II type 1 receptor in pancreatic cancer. IUBMB Life. 2015; 67:42-53. https://doi.org/10.1002/iub.1342.

43. Zhang X, Zheng L, Sun Y, Wang T, Wang B. Tangeretin enhances radiosensitivity and inhibits the radiation-induced epithelial-mesenchymal transition of gastric cancer cells. Oncol Rep. 2015; 34:302-10. https://doi.org/10.3892/ or.2015.3982.

44. Song JX, Lu JH, Liu LF, Chen LL, Durairajan SS, Yue Z, Zhang HQ, Li M. HMGB1 is involved in autophagy inhibition caused by SNCA/ $\alpha$-synuclein overexpression: a process modulated by the natural autophagy inducer corynoxine B. Autophagy. 2014; 10:144-54. https://doi. org/10.4161/auto.26751.
45. Kang R, Zhang Q, Zeh HJ 3rd, Lotze MT, Tang D. HMGB1 in cancer: good, bad, or both? Clin Cancer Res. 2013; 19:4046-57. https://doi.org/10.1158/1078-0432.CCR-13-0495.

46. Liu L, Yang M, Kang R, Wang Z, Zhao Y, Yu Y, Xie M, Yin X, Livesey KM, Lotze MT, Tang D, Cao L. HMGB1induced autophagy promotes chemotherapy resistance in leukemia cells. Leukemia. 2011; 25:23-31. https://doi. org/10.1038/leu.2010.225.

47. Koshkina NV, Briggs K, Palalon F, Curley SA. Autophagy and enhanced chemosensitivity in experimental pancreatic cancers induced by noninvasive radiofrequency field treatment.Cancer. 2014; 120:480-91. https://doi.org/10.1002/ cncr. 28453 .

48. Donadelli M, Dando I, Zaniboni T, Costanzo C, Dalla Pozza E, Scupoli MT, Scarpa A, Zappavigna S, Marra M, Abbruzzese A, Bifulco M, Caraglia M, Palmieri M. Gemcitabine/cannabinoid combination triggers autophagy in pancreatic cancer cells through a ROS-mediated mechanism. Cell Death Dis. 2011; 2:e152. https://doi.org/10.1038/cddis.2011.36.

49. Wang Z, Wang N, Liu P, Chen Q, Situ H, Xie T, Zhang J, Peng C, Lin Y, Chen J. MicroRNA-25 regulates chemoresistance-associated autophagy in breast cancer cells, a processmodulated by the natural autophagy inducer isoliquiritigenin. Oncotarget. 2014; 5:7013-26. http://doi. org/10.18632/oncotarget.2192.

50. Sun Q, Liu T, Yuan Y, Guo Z, Xie G, Du S, Lin X, Xu Z, Liu M, Wang W, Yuan Q, Chen L. MiR-200c inhibits autophagy and enhances radiosensitivity in breast cancer cells by targetingUBQLN1. Int J Cancer. 2015; 136:1003-12. https://doi.org/10.1002/ijc.29065.

51. Chen $\mathrm{R}, \mathrm{Li} \mathrm{X}, \mathrm{He} \mathrm{B}, \mathrm{Hu}$ W. MicroRNA-410 regulates autophagy-related gene ATG16L1 expression and enhanceschemosensitivity via autophagy inhibition in osteosarcoma. Mol Med Rep. 2017; 15:1326-1334. https:// doi.org/10.3892/mmr.2017.6149. 